\title{
The prevalence of stress urinary incontinence in women studying nursing and related quality of life
}

\author{
Józef Opara ${ }^{1}$ Wioletta Ewa Czerwińska-Opara² \\ ${ }^{1}$ Akademia Wychowania Fizycznego im. Jerzego Kukuczki w Katowicach \\ ${ }^{2}$ Wyższa Szkoła Planowania Strategicznego w Dąbrowie Górniczej
}

\begin{abstract}
Urinary incontinence is a growing problem that affects millions of people worldwide. The purpose of this study was to assess the prevalence of stress urinary incontinence (SUI) in women studying nursing. Respondents completed a questionnaire assessing urinary incontinence, severity of symptoms and quality of life. Short forms to assess symptoms of distress for urinary incontinence and quality of life: UDI- 6 and IIQ-7 have been used. The study's conclusions are as follows: 1) among the 113 interviewed women, stress urinary incontinence (SUI) was observed in $25 \%$ of respondents; this prevalence is similar to the age-matched population; 2 ) among the triggering factors mentioned in stress urinary incontinence the most frequent were: coughing, laughing and sneezing; 3) moderate impact of incontinence on quality of life has been shown, but this effect was not statistically significant.
\end{abstract}

Key words: stress urinary incontinence, prevalence, quality of life.

\section{Introduction}

Millions of women experience a leak or involuntary loss of urine. The most common types of urinary incontinence $(\mathrm{UI})$ in women are stress urinary incontinence and urge urinary incontinence. Women with both problems have mixed urinary incontinence. Stress urinary incontinence (SUI) was defined by the International Urogynecological Association and International Continence Society as "complaint of involuntary loss of urine on effort or physical exertion (e.g. sporting activities), or on sneezing or coughing" [1, 2]. Stress urinary incontinence, also known as effort incontinence, is due essentially to insufficient strength of the pelvic floor muscles and caused by loss of support of the urethra. It is characterized by leaking of small amounts of urine during activities which increase abdominal pressure such as coughing, laughing, sneezing, climbing stairs, running and lifting. It can be a common and distressing problem, which may have a profound impact on quality of life, including sexual life. Stress urinary incontinence leads to decreased quality of life in sufferers, especially in women over 60 years old, and financial burdens for both the patient and the healthcare industry [3]. Urinary incontinence almost always results from an underlying treatable medical condition but is underreported to medical practitioners.

The prevalence of $\mathrm{UI}$ increases with age, with a typical rate in young adults of $20-30 \%$, a peak around mid- dle age (prevalence 30-40\%) and a steady increase at the old age (prevalence 30-50\%) [4]. Following Luber, SUI has an observed prevalence of between $4 \%$ and $35 \%$ [4]. Whereas the clinical definition of SUI has been established, the epidemiologic definition has not been established, leading to a broad disparity in reported prevalence rates [5]. In Hunskar et al. survey in four European countries of 17080 community-dwelling women aged $\geq 18$ years who responded, $35 \%$ reported involuntary loss of urine in the preceding 30 days; and SUI was the most prevalent type. The lowest prevalence of UI was in Spain (23\%), while the prevalence was 44\%, $41 \%$ and $42 \%$ for France, Germany and the UK, respectively [4]. Bidzan, according to statistics from inpatient and outpatient gynecological and urological departments stated that SUI occurs in approximately $35 \%$ of patients over 45 years [6].

Numerous risk factors for SUI have been identified. Aging, obesity, and smoking appear to have consistent causal relationships with the condition, whereas the roles of pregnancy and childbirth remain controversial [7]. A review of the literature shows that other factors predisposing to urinary incontinence are: genetic factors, female gender, white race, pregnancy, childbirth, hysterectomy, menopause, heavy physical work and grueling physical training [7-10]. On the other hand, it is well known that regular physical activity protects against SUI [8]. In the USA, in the National Health 
and Nutrition Examination Survey 2001-2002, data on $\mathrm{UI}$ in 2,875 adult women were estimated. The overall prevalence of stress, urge, mixed, and any UI was $23.7 \%, 9.9 \%, 14.5 \%$, and $49.2 \%$, respectively. Prevalence of SUI peaked at the fifth decade. Prevalence of urge and mixed UI increased with age. The largest number of risk factors and the strongest associations were found with severe UI. Age, ethnic background, and weight were significant risk factors common to all UI severity levels [11].

The aim of this study was: 1) to evaluate the prevalence of stress urinary incontinence (SUI) among women studying nursing, and 2) to assess the impact of in continence on quality of life $(\mathrm{Q} o \mathrm{~L})$.

\section{Material and methods}

113 of 190 women studying nursing at a higher level completed the questionnaires. Inclusion criteria were: female gender, occupation (nurse), and lack of nervous system disorders affecting the function of the bladder. Exclusion criteria were: male gender, profession other than a nurse, and diseases of the nervous system affecting the function of the bladder. Respondents have been informed about the purpose of research, symptoms of SUI and that participation in this survey is anonymous and voluntary. The age of 113 subjects ranged between 25 and 55 years, average 40.5 years.

For evaluation of symptoms of distress for $\mathrm{UI}$ and QoL, two short questionnaires have been used: UDI-6 and IIQ-7. Urogenital Distress Inventory (UDI-6 Short Form) concerns the last three months. If the respondent answers "yes", the next question is "how much does this bother you?". Scoring is as follows: not at all = 1 point, somewhat $=2$, moderately $=3$, quite a bit $=4$. Item 3 refers to SUI. To obtain the Index of Urinary Problems (IUP), the mean value of all the answered items must be divided by 6 and multiplied by 25. IUP could be in the range of 0 to 100 where 0 means no disturbance. The index in the range 1-25 means slight impairment, 26-50 - moderate, 51-75 - substantial and 75-100 - severe [12]. Incontinence Impact Questionnaire - Short Form 7 (IIQ-7) contains seven questions about the impact of urinary incontinence on QoL. Questions 1 and 2 relate to physical activity, questions 3 and 4 - travel, question 5 - social life/relationships, and questions 6 and 7 - emotional

Table I. SUI depending on age $(n=113)$

\begin{tabular}{lcccc}
\hline & $\begin{array}{c}\text { Age 25-40 } \\
\text { years } \\
(\boldsymbol{n}=\mathbf{5 7})\end{array}$ & $\begin{array}{c}\text { Age 41-55 } \\
(\boldsymbol{n}=\mathbf{5 6})\end{array}$ & $\begin{array}{c}\text { Total } \\
(\boldsymbol{n}=\mathbf{1 1 3})\end{array}$ & Significance \\
\hline SUI & $12(21 \%)$ & $16(28 \%)$ & $28(25 \%)$ & \\
$\chi^{2}$ & & & & $p=0.3089$ \\
Fisher's & & & $p=0.4114$ \\
test & & & \\
\hline
\end{tabular}

health. Item responses are assigned values of 0 for "not at all", 1 for "slightly", 2 for "moderately", and 3 for "greatly". The average score of items answered is calculated. The average, which ranges from 0 to 3 , is multiplied by $331 / 3$ to put scores on a scale from 0 to 100 . Score 0 means no problems. Urinary Incontinence Impact Indicator (UIII) in the range of 1-25 means a slight disturbance, 26-50 -moderate, 51-75 - substantial and 75100 - severe [12]. For statistical analysis, chi square $\left(\chi^{2}\right)$ and Fischer's test have been used.

\section{Results}

Stress urinary incontinence at least once a month was reported by 27 out of 113 respondents - this represented $25 \%$ of the respondents (Table I). Among 57 people aged 25 to 40 years, SUI occurred in 12 subjects $(21 \%)$, and in a subgroup of 56 people aged 41 to 55 years, SUI occurred in 16 subjects, i.e. $28 \%$. The problem of incontinence often concerned respondents aged $\geq 41$ years, although these differences were not statically significant $\left[\chi^{2} p(1\right.$ vs. 2$)=0.3089$, Fischer's test $p(1$ vs. 2$)=0.4114$ ] (Table 1$)$. Stress urinary incontinence took 1 to 19 years, an average of 5.4 years.

As for circumstances of urine leakage: 23 out of 28 (i.e. 82\%) subjects with SUI loosed urine due to the impact of coughing, laughing, or sneezing, whereas 15 subjects (53\%) when climbing stairs, running or lifting (Table II).

The biggest distress associated with loosening of urine appeared when coughing, sneezing or laughing (Table III).

Urine incontinence often resulted in a feeling of frustration; this involved 19 patients of 28 (i.e. 68\%). Frustration with UI was the most severe in 8 (i.e. $28.5 \%$ ) of the respondents (Table IV).

The Urinary Incontinence Impact Indicator (UIII) of 28 respondents showed that in $4(14 \%)$ subjects there was no impact of UI, slight impact occurred in 12 subjects (43\%), moderate in 5 persons (18\%), significant impact in 3 persons (11\%), and severe in 4 respondents (14\%).

\section{Discussion}

Based on the above results one can state that stress urinary incontinence (SUI) in the material occurred in $25 \%$ of 113 respondents. Stress urinary incontinence occurred more frequently between the age of 41 and 55 than at the age of 25-40, but not statistically sig-

Table II. Circumstances of urine leakage $(n=28)$

\begin{tabular}{lcc}
\hline $\begin{array}{l}\text { Leakage } \\
\text { of urine }\end{array}$ & $\begin{array}{c}\text { Due to coughing, } \\
\text { laughing or sneezing }\end{array}$ & $\begin{array}{c}\text { During climbing stairs, } \\
\text { running or lifting }\end{array}$ \\
\hline SUI & $23(82 \%)$ & $15(53 \%)$ \\
\hline
\end{tabular}


Table III. Perceived distress associated with loosening of urine in UDI-6 $(n=28)$

\begin{tabular}{|c|c|c|c|c|c|c|}
\hline & Symptom & Not at all & Somewhat & Moderately & Quite a bit & Total \\
\hline 1 & Frequent urination & $2(7 \%)$ & $0(0 \%)$ & $12(43 \%)$ & $2(7 \%)$ & $16(57 \%)$ \\
\hline 2 & Urine leakage associated with urgency & $0(0 \%)$ & $6(28.5 \%)$ & $3(11 \%)$ & $7(25 \%)$ & $16(57 \%)$ \\
\hline 3 & Urine leakage related to coughing, sneezing, or laughing & $0(0 \%)$ & $5(18 \%)$ & $9(32 \%)$ & $12(43 \%)$ & $26(93 \%)$ \\
\hline 4 & Urine leakage in drops & $0(0 \%)$ & $5(18 \%)$ & $6(21 \%)$ & $8(36 \%)$ & $19(68 \%)$ \\
\hline 5 & Difficulty emptying bladder & $0(0 \%)$ & $4(14 \%)$ & $5(18 \%)$ & $2(7 \%)$ & $11(30 \%)$ \\
\hline 6 & Pain or discomfort in the lower abdomen & $0(0 \%)$ & $2(7 \%)$ & $4(14 \%)$ & $7(25 \%)$ & $13(46 \%)$ \\
\hline $6 a$ & Pain relieved after emptying bladder (totally in $71 \%$ ) & & & & & 10 out of 14 \\
\hline
\end{tabular}

Table IV. Impact of urine incontinence on Quality of Life in IIQ-7 $(n=28)$

\begin{tabular}{llccccc}
\hline & Impact & No & Not at all & Moderately & Greatly & Total \\
\hline 1 & Household chores & $0(0 \%)$ & $3(11 \%)$ & $2(7 \%)$ & $3(11 \%)$ & $8(28.5 \%)$ \\
\hline 2 & Physical recreation & $0(0 \%)$ & $7(25 \%)$ & $0(0 \%)$ & $5(18 \%)$ & $12(43 \%)$ \\
\hline 3 & Entertainment & $0(0 \%)$ & $3(11 \%)$ & $2(7 \%)$ & $4(14 \%)$ & $9(32 \%)$ \\
\hline 4 & Travel by car or bus & $0(0 \%)$ & $3(11 \%)$ & $2(7 \%)$ & $5(18 \%)$ & $10(36 \%)$ \\
\hline 5 & Social activities & $0(0 \%)$ & $2(7 \%)$ & $5(20 \%)$ & $3(11 \%)$ & $10(36 \%)$ \\
\hline 6 & Emotional health & $0(0 \%)$ & $3(11 \%)$ & $4(14 \%)$ & $5(18 \%)$ & $12(43 \%)$ \\
\hline 7 & Feeling of frustration & $0(0 \%)$ & $7(25 \%)$ & $4(14 \%)$ & $8(28.5 \%)$ & $19(68 \%)$ \\
\hline
\end{tabular}

nificant. More respondents with SUI loosed urine under the impact of coughing, laughing, or sneezing, and less when climbing stairs, running or lifting. Results of short questionnaire UDI-6 showed the greatest distress associated with loosening of urine when coughing, sneezing or laughing. As for impact of urine incontinence measured in short questionnaire IIQ-7: many respondents reported feelings of frustration. The impact of UI on activity appeared to be low.

The prevalence of SUI in this survey $(25 \%$ of the respondents) is similar to that reported for women at the age 25-55 in the literature on epidemiology of UI. It should be noted that a number of patients never meet the doctor [6]. Keyock and Newman indicate that UI is both underreported and undertreated. They outline the role of the nurse practitioner in identifying, diagnosing, managing, and treating SUI [3]. Nurses should encourage women to practice pelvic floor exercises, which are the best way of prevention SUI especially after delivery [13-20].

There is only one report in the literature referring to $\mathrm{UI}$ in nurses. Of 116,671 female nurses aged 25 to 42 years in 14 states of America, who in 1989, started the Nurses' Health Study II, in 2001, 64,650 women aged 36-55 years completed a mailed questionnaire. Participants reported urine leaking in 2001 and 2003. The 2-year incidence of incontinence was $13.7 \%$. Incidence generally increased until the age of 50 years and then declined slightly in older women. Among women with incident incontinence at least weekly, the incidence of SUI increased until the age of 50 years (2-year incidence $1.7 \%$ ), and the incidence of urge incontinence was stable across age groups (2-year incidence $0.4 \%)$. Also, a minority (38\%) mentioned leaking to their physician [21].

These are many clinimetrics methods of evaluation of UI. There are simplifications of the 19-item UDI and 30-item IIQ to 6 and 7 item short forms, respectively. The short form versions, made in 1995 by Uebersax et al., may be more useful than the long form versions in many clinical and research applications [12, 22]. As for assessment of QoL related to $\mathrm{UI}$, the most commonly instruments are: Incontinence Quality of Life (I-QoL), Incontinence Impact Questionnaire-short form (IIQ-7), and King's Health Questionnaire (KHQ) [23-26]. We stated that Urogenital Distress Inventory (UDI-6) was more useful to assess the problems associated with SUI for our study group than Incontinence Impact Questionnaire (IIQ-7) which is the questionnaire on quality of life. The questionnaire IIQ-7 showed a modest reduction in quality of life.

In the Prospective Urinary Incontinence Research (PURE) 6-mo observational study in 15 European countries, 9487 women was enrolled. Quality of Life was assessed at the enrolment visit using the urinary Incontinence Quality of Life questionnaire (I-QOL) and the generic EQ-5D. A single-item instrument was used to measure the degree of bother. Urinary incontinence severity was assessed using the Sandvik Index. Urinary incontinence was categorized into stress (SUI), mixed (MUI), and urge (UUI) urinary incontinence by a patient-administered instrument (Stress and Urge Incontinence Questionnaire [S/UIQ]). Mean total I-QOL scores were significantly and independently associated with UI severity, nocturia, age, UI subtype, number of 
selected concomitant medical conditions, length of suffering from UI before contacting a doctor, smoking status, ongoing use of UI medication, and country [27].

Dąbrowska et al. stated that physical activity is one of the major lifestyle-related determinant which directly or indirectly influences different life components during menopause [28]. Barnaś et al. evaluated the impact of selected socio-demographic factors on the course of menopause and their influence on women's quality of life in 256 menopausal women aged between 48 and 58. They concluded that menopause complaints, insufficient financial status, lack of hormonal therapy, and the lack of satisfaction with one's sexual life determine poor psychosocial and occupational functioning, which decreases the quality of life of women in menopause [29].

\section{Conclusions}

1. Among the 113 interviewed women, stress urinary incontinence was observed in $25 \%$ of respondents. This prevalence is similar to the age-matched population.

2. Among the triggering factors mentioned in stress urinary incontinence, the most frequent were: coughing, laughing and sneezing.

3. Moderate impact of incontinence on quality of life has been shown, but this effect was not statistically significant.

\section{Disclosure}

Authors report no conflicts of interest.

\section{References}

1. Nygaard IE, Heit M. Stress urinary incontinence. Obstet Gynecol 2004; 104: 607-620.

2. Haylen BT, de Ridder D, Freeman RM, et al.; International Urogynecological Association; International Continence Society. An International Urogynecological Association (IUGA)/International Continence Society (ICS) joint report on the terminology for female pelvic floor dysfunction. Neurourol Urodyn 2010; 29: 4-20.

3. Keyock KL, Newman DK. Understanding stress urinary incontinence. Nurse Practitioner 2011; 36: 24-36.

4. Hunskaar S, Lose G, Sykes D, Voss S. The prevalence of urinary incontinence in women in four European countries. BJU International 2004; 93: 324-330.

5. Luber KM. The definition, prevalence, and risk factors for stress urinary incontinence. Rev Urol 2004; 6 Suppl 3: S3-S9.

6. Bidzan M. Jakość życia pacjentek z różnym stopniem nasilenia wysiłkowego nietrzymania moczu. Impuls, Kraków 2008.

7. Gyhagen M, Bullarbo M, Nielsen T, et al. The prevalence of urinary incontinence 20 years after childbirth: a national cohort study in singleton primiparae after vaginal or caesarean delivery. BJOG 2013; 120: 144-151.
8. Płachta Z, Mazur P, Walaszek P, et al. Nietrzymanie moczu u kobiet - epidemiologia i czynniki ryzyka. Prz Menopauz 2002; 6: 28-32.

9. Opara JA, Socha T, Bidzan M, et al. Stress urine incontinence especially in elite women athletes extremely practicing sports. Arch Budo 2011; 7: OF227-OF231.

10. Stothers L, Friedman B. Risk factors for the development of stress urinary incontinence in women. Curr Urol Rep 2011; 12: 363-369.

11. Minassian VA, Stewart WF, Wood GC. Urinary incontinence in women: variation in prevalence estimates and risk factors. Obstetrics Gynecol 2008; 111: 324-331.

12. Uebersax JS, Wyman JF, Shumaker SA, et al. Short forms to assess life quality and symptoms distress for urinary incontinence in women: the Incontinence Impact Questionnaire and the Urogenital Distress Inventory. Neurourol Urodyn 1995; 14: 131-139.

13. Adamczuk J, Kraczkowski J, Robak J, et al. Rola położnej a oczekiwania kobiet z wysiłkowym nietrzymaniem moczu. Probl Hig Epidemiol 2011; 92: 675-678.

14. Chmielewska D, Kwaśna K, Piecha M, et al. Selected methods of conservative treatment of stress urinary incontinence: current views. Part 1. Wybrane metody zachowawczego leczenia wysitkowego nietrzymania moczu - aktualne poglądy. Część 1. Prz Menopauz 2012; 16: 264-268.

15. Dumoulin C, Martin C, Elliott V, et al. Randomized controlled trial of physiotherapy for postpartum stress incontinence: 7-year follow-up. Neurourol Urodyn 2013; 32: 449-554.

16. Kegel AH. Progressive resistance exercise in the functional restoration of the perineal muscles. Am J Obstet Gynecol 1948; 56: 238-249.

17. Kwaśna K, Chmielewska D, Piecha M, et al. Wybrane metody zachowawczego leczenia wysiłkowego nietrzymania moczu - metody fizjoterapeutyczne. Część 2. Prz Menopauz 2012; 16: 372-375.

18. Opala-Berdzik A, Poręba R, Chmielewska D. Współczesne fizjoterapeutyczne metody leczenia wysiłkowego nietrzymania moczu u kobiet. Fizjoter Pol 2005; 5: 364-368.

19. Opara J, Socha T, Prajsner A, et al. Fizjoterapia w wysiłkowym nietrzymaniu moczu u kobiet. Część I. Aktualne rekomendacje dotyczące ćwiczeń według Kegla. Fizjoterapia 2011; 19: 41-49.

20. Sahakian J. Stress incontinence and pelvic floor exercises in pregnancy. Br J Nurs 2012; 21: S10, S12-S15.

21. Townsend MK, Danforth KN, Lifford KL, et al. Incidence and remission of urinary incontinence in middle-aged women. Am J Obstetrics Gynecol 2007; 197: 167.e1-167.e5.

22. Wlaźlak E, Surkont G, Stetkiewicz T, et al. Wpływ wybranych metod nieoperacyjnego leczenia wysiłkowego nietrzymania moczu (WNM) na jakość życia pacjentek. Prz Menopauz 2005; 9: 53-60.

23. Borowski J, Radziszewski P, Borkowski A. Jakość życia kobiet z nadreaktywnością pęcherza moczowego. Prz Menopauz 2008; 12: 168-170.

24. Kelleher CJ, Cardozo LD, Khullar V, et al. A new questionnaire to assess the quality of life of urinary incontinent women. Br J Obstet Gynaecol 1997; 104: 1374-1379.

25. Kieres P, Rokita W, Stanisławska M, et al. The diagnostic value of chosen questionnaires (UDI 6SF, Gaudenz, MESA, ICIQ-SF and King's Health Questionnaire) in diagnosis of different types of women's urinary incontinence. Ginekol Pol 2008; 79: 338-341.

26. Kwon BE, Kim GY, Son YJ, et al. Quality of life of women with urinary incontinence: a systematic literature review. Int Neurourol J 2010; 14: 133-138.

27. Monz B, Chartier-Kastler E, Hampel C, et al. Patient characteristics associated with quality of life in European women seeking treatment for urinary incontinence: results from PURE. Eur Urol 2007; 51: 1073-1082.

28. Dąbrowska J, Naworska B, Dąbrowska-Galas M, et al. The role of physical activity in menopause. Prz Menopauz 2012; 16: 445-448.

29. Barnaś E, Krupińska A, Kraśnianin E, et al. Psychosocial and occupational functioning of women in menopause. Prz Menopauz 2012; 16: 296-304. 